MERCATORIA

Available online http://ojs.uma.ac.id/index.php/mercatoria

\title{
Hak-Hak Perempuan Dalam Hukum Islam (Studi Pemikiran Ashgar Ali Engineer)
}

\author{
Khairul Mufti Rambe*
}

\author{
Universitas Islam Negeri Sumatera Utara
}

*Corresponding author: E-mail: khairulmufti_rambe@yahoo.com

\begin{abstract}
Abstrak
Guna membentuk pola pemikiran modern yang menyelaraskan rumusan hukum yang senantiasa segar dan transformatif haruslah berdasarkan nilai-nilai ketuhanan, dengan melahirkan pola hukum yang setara dan adil khususnya dalam Hukum Keluarga Islam. Hukum Islam haruslah mengacu pada nilai-nilai fundamental yang terkandung di dalam Al-Qur'an, yaitu: 'adl (keadilan), ihsan (kebajikan), rahmah (kasih sayang), hikmah\} (kearifan) dan menjunjung tinggi martabat manusia, maka hasilnya adalah terciptanya keadilan gender dengan membangun relasi antara laki-laki dan perempuan sesuai dengan nilai-nilai semangat Al-Qur'an. Dengan demikian, perempuan bisa menjadi icon dalam setiap wilayah baik publik maupun domestik, dan hukum personal yang dibentuk bisa mencapai stratifikasi shalihun likulli zaman wa al makan.
\end{abstract}

Kata kunci : Hak-hak perempuan, Hukum Islam

\section{Abstract}

In order to form a modern pattern of thought that harmonizes the fresh and transformative legal formula must be based on divine values, by creating equitable and fair patterns of law, especially in the Family Law of Islam. Islamic law must refer to the fundamental values contained in the Qur'an, namely: 'adl (justice), ihsan (virtue), rahmah (affection), hikmah (wisdom) and upholds human dignity, then The result is the creation of gender justice by building relationships between men and women in accordance with the values of the spirit of the Qur'an. Thus, women can become icons in every region both public and domestic, and personal laws that are formed can achieve stratification shalihun likulli zaman wa al makan.

Keyword: Woman's rights, Islamic Law

How to Cite: Rambe, K.M., (2017), Hak-Hak Perempuan Dalam Hukum Islam (Studi Pemikiran Ashgar Ali Engineer), Mercatoria, 10 (2): 109-127. 
Khairul Mufti Rambe, Hak-Hak Perempuan Dalam Hukum Islam (Studi Pemikiran Ashgar Ali Engineer)

\section{PENDAHULUAN}

Ketika perempuan dipersandingkan dengan laki-laki yang dihimpun dalam satu perkawinan yang sah menurut agama, maka terbentuklah satu wadah baru yang dinamakan "keluarga" yang akan melahirkan generasi baru sebagai rotasi kehidupan manusia yang berevolusi. Pemerintahan terkecil atau keluarga yang terbentuk dari keluarga itu pada dasarnya adalah mengumpulkan dua pribadi dalam satu keluarga. Perkawinan juga merupakan kesepakatan sosial antara seorang laki-laki dan perempuan untuk menempuh hidup bersama. Keadaan demikian dinamakan sebagai suami istri yang menyebabkan seorang perempuan menerima hukum-hukum seperti mas kawin, perceraian, 'iddah dan waris. ${ }^{1}$

Seiring dengan terbentuknya keluarga baru, kesetaraan laki-laki dan perempuan dalam hak dan kewajiban dipertanyakan. Penyebabnya tekanan perempuan, eksploitasi dan tekanan sosial yang mereka alami yang bukan merupakan ciri masyarkat dari benua manapun atau Negara-negara "Dunia Ketiga" semuanya bagian yang integral dari sistem politik ekonomi dan budaya yang berpengaruh besar dalam hampir seluruh dunia, baik sistem itu melingkupi masyarakat terbelakang dan masih bersifat feodal, atau yang mewarnai masyarakat industri modern yang mengarah kepada revolusi sains dan teknologi. ${ }^{2}$

${ }^{1}$ Muhammad Shahrur, Metodologi Fikih Islam Kontemporer, terj. Syahiron Syamsuddin, (Yogyakarta: Elsak, 2004), hlm. 434.

${ }^{2}$ Nawawi el-Sadawi, Perempuan dalam Budaya Patrialki, terj. Zulhilmiyasri (Yogayakarta: Pustaka Pelajar, 2001), hlm. v.
Keadaan dan persoalan-persoalan kaum wanita dalam masyarakat kontemporer lahir dari perkembangan dalam sejarah, yang membuat suatu kelas menguasai kelas yang lain dan laki-laki menguasi kelas perempuan. Untuk menjembatani kesenjangan ini Islam memberikan konsep kesetaraan (almusawah) dalam Al-Qur'an, tetapi pada perkembangannya sudut pandang dari pemikir-pemikir Islam dalam menafsirkan teks Al-Qur'an terhadap konteks kesetaraan ini menjadi paradoks. Hal ini disebabkan lantaran Al-Qur'an dan Sunnah yang menjadi teks suci, dan umat Islam mengesankan gambaran yang kontradiktif tentang hubungan antara perempuan dan laki-laki.

Di beberapa ayat Al-Qur'an menjelaskan bahwa posisi laki-laki dan perempuan adalah setara. Misalnya perempuan diciptakan oleh Tuhan bersama dengan laki-laki dan dari keduanya berkembang keturunan mereka dipermukaan bumi. ${ }^{3}$

Penafsiran Al-Qur'an memang sering dijadikan dasar untuk menolak kesetaraan gender. Kitab-kitab tafsir dijadikan sebagai referensi dalam mempertahankan status quo dan melegalkan pola hidup patrialki, yang memberikan hak-hak istimewa kepada laki-laki dan cenderung memojokkan perempuan. Laki-laki dianggap sebagai jenis kelamin utama dan perempuan dianggap sebagai jenis kelamin kedua (the second sex). Anggapan seperti ini mengendap dibawah alam sadar masyarakat dan membentuk etos kerja

${ }^{3}$ Q.S an Nisa' (4): 1. 
yang timpang antara kedua jenis hamba Tuhan tersebut. 4

Ajaran-ajaran yang menempatkan perempuan sebagai makhluk nomor dua dibawah laki-laki biasanya dikategorikan sebagai bagian dari pemahaman Islam tradisional, yang dinilai sudah tidak sejalan dengan perkembangan dan nilainilai kemanusiaan pada era modern ini. ${ }^{5}$ Sekalipun dianggap tradisional pemahaman ini tetap saja ada dan tumbuh entah sampai kapan.

Termasuk salah satu agenda nabi adalah pembebasan perempuan dari kungkungan kultur patrialki Arab. Pada saat itu posisi perempuan sangat lemah yang dihadapan dengan laki-laki. Mereka tidak hanya ditindas dan diperbudak, bahkan mereka bisa diwariskan seperti barang. ${ }^{6}$ Nabi kemudian meninggikan derajat perempuan dengan beberapa perubahan yang sesuai dengan kondisi pada saat itu, bahkan Al-Qur'an memberikan status pasti kepada perempuan, walau tidak sejajar dengan laki-laki.

Namun produk hukum yang dibentuk dalam lingkaran budaya patrialki Arab belum bisa melepaskan diri dari pengaruh kultur tersebut. Ketidaksejajaran status perempuan dan laki-laki dapat dilihat dalam produk Hukum Keluaga Islam saat ini, misalnya dalam perkawinan yang tidak banyak melibatkan perempuan. Dalam beberapa

${ }^{4}$ Nasaruddin Umar, Qur'an untuk Perempuan, (Jakarta: Jaringan Islam Liberal, dan Teater Utan Kayu, 2002), hlm. 1.

${ }^{5}$ Faisar Ananda, Wanita Dalam Konsep Islam Modernis, (Jakarta: Pustaka Firdaus, 2004), hlm. 10.

${ }^{6} \mathrm{Fr}$ Wahono Nitiprawiro, Teologi Pembebasan: Sejarah, Metode, Praksis dan Isinya, cet I, (Yogyakarta: LKiS, 2002) hlm. 1001-1002. aspek Hukum Keluarga terdapat beberapa hak perempuan yang berbeda dengan hak yang dimiliki laki-laki. Misalnya dalam hal akad, menurut mazhab Syafi'i pihak perempuan tidak diperbolehkan melakukan akad sendiri, yang terlibat dalam akad adalah wali mempelai perempuan, yang juga harus laki-laki dengan pihak mempelai laki-laki. ${ }^{7}$

Terjadinya perbedaan hak laki-laki dan perempuan memang tidak dapat dielakkan. Al-Qur'an sebagai sumber utama hukum keluaga Islam sendiri telah menetapkan beberapa hukum yang berbeda antar laki-laki dan perempuan, bahkan sering kali laki-laki mendapatkan hak yang lebih menguntungkan dibanding perempuan. Hal demikian karena AlQur'an sebagai sumber yang otoritatif juga ikut menentukan doktrin-doktrin teologis yang berkembang dikalangan ummat pemeluknya. Pada gilirannya setelah doktrin itu diterima secara luas oleh mereka, maka hadits bisa mempengaruhi budaya mereka, bahkan menurut studi J. Fueck, bisa mempersatukannya. ${ }^{8}$ Pernikahan lintas agama misalnya, dalam Al-Qur'an disebutkan bahwa seorang lakilaki dapat menikahi seorang perempuan ahlu al-kitab, sementara perempuan tidak diperkenankan menikah dengan laki-laki ahlu al-kitab.

Dalam lembaga perkawinan inilah sering kali perempuan mendapat perlakuan berbeda dengan laki-laki.

${ }^{7}$ Abi Ishaq Ibrahim ibnu Ali ibnu Yusuf alFairuzzabady, al-Muhazzab fi Mazhab al-Imam asySyafi 'i (Beirut: Dar al Fiqr, 1994 M/1414 H), II, hlm. 50.

${ }^{8}$ Hamim Ilyas, Perempuan Tertindas: Kajian Hadits-hadits Misoginis, (Yogyakarta: eLSAQ Press, 2003), hlm. 51. 
Khairul Mufti Rambe, Hak-Hak Perempuan Dalam Hukum Islam (Studi Pemikiran Ashgar Ali Engineer)

Bahkan Al-Qur'an sendiri juga saudara laki-lakinya, sebagai seorang istri melegitimasi kekerasan terhadap perempuan dalam rumah tangga dengan alasan pendidikan. ${ }^{9}$ Kesetaraaan terhadap hak laki-laki dan perempuan inilah yang dianggap sebagai ketidakadilan agama terhadap perempuan. Namun sangatlah ironis agama lahir membawa ketidakadilan. Apakah benar ajaran yang memberikan perbedaan antara laki-laki dan perempuan dapat disebut sebuah keadilan?.

Perkembangan dengan adanya klasifikasi gender akan memberikan pengaruh kepada pemahaman hak wanita yang signifikan dalam keluarga. Ada atau tidaknya ambiguitas dalam Al-Qur'an tentang hak wanita dalm keluarga. Maka penulis mengemukakan rujukan ayat yang menjadi patokan dalam kajian tersebut yaitu Q.S An Nisa' (4): 32.

Bertitik tolak dari ayat diatas penulis melihat gambaran hak perempuan dalam keluarga tampaklah sudah, respon penafsiranlah yang menjadikannya tertumpuh ke dalam banyak penafsiran, namun ayat diatas bukanlah satu-satunya dasar rujukan tentang hak perempuan dalam keluarga, sebahagian besar mufassir memang menjadikan ayat diatas sebagai landasan dalam berkeluarga dan kepemimpinannya.

Peran dan status perempuan dalam perspektif Islam ini selalu dikaitkan dengan keberadaan laki-laki. Perempuan digambarkan sebagai makhluk yang keberadaannya sangat tergantung kepada laki-laki. Sebagai seorang anak, ia berada dibawah lindungan perwalian ayah dan

${ }^{9}$ Q.S An Nisa' (4); 4.

${ }^{10}$ Faisar Ananda, Wanita Dalam Konsep Islam Modernis, hlm. 11.

${ }^{11}$ M. Quraisy Shihab, Membumikan al-Qur'an fungsi dan Peran Wahyu dalam Kehidupan Masyarkat, cet XXII (Bandung: Mizan, 2001), hlm. 26. Lihat juga Muhammad al Ghazali, al-Islam wa at-Thaqat alMu'attalat, (Kairo: Dar al-Kutub al-Haditsah, 1964), hlm. 138. 
dalam Hukum Keluarga Islam dengan pendekatan analisis sejarah (historical analysis) terhadap konsep teologi pembebasan yang dimilikinya dengan membentuk kesetaraan (equality) yang menghasilkan pada nilai-nilai keadilan sosial (social justice). Perumusan teologi tersebut berawal dari suatu wacana perempuan yang mudah dieksploitasi laki-laki sehingga merampas hak-hak dan kebebasannya sebagai manusia yang mempunyai hak. Padahal Islam datang membawa nilai-nilai kebebasan manusia. Kebebasan tersebut adalah merupakan hadiah dari Allah SWT kepada manusia yang harus digunakan, tapi kenyataannya manusia kembali menjadi zhalim dimana yang kuat menyerang yang lemah, dan yang lemah semakin tertindas, disinilah nasib perempuan semakin menyedihkan.

Sebagai konstruksi sosial, keberagaman akan menampilkan wajah tunggal di antara pemeluk agama itu sendiri. Lebih dari itu, penafsiran terhadap ayat-ayat suci juga melahirkan perbedaan pandapat, karena kitab suci sendiri hadir tidak dalam ruang kosong, apakah seseorang menafsirkan kitab suci semata-mata dari teksnya, atau dari "ruh" atau malah ada konsep tersendiri yang ada dibalik teks itu. Dengan asusmsi seperti ini, maka tafsir terhadap agama sesungguhnya sangat ditentukan oleh "kepentingan" individu pemeluk agama secara umum.

\section{HASIL DAN PEMBAHASAN}

Pemahaman Baru terhadap Pemikiran Ashgar Ali Engineer tentang Hak-hak Perempuan dalam Hukum Keluarga Islam

Setelah melakukan pendeskripsian pemikiran Engineer, maka selanjutnya akan dikemukana analisis yang akan menguak hasil dari pemikiran Engineer, bahwa Engineer mengakui historisitas AlQur'an, ketetapan-ketetapan Al-Qur'an bukanlah merupakan hukum mati yang berlaku sepanjang masa, ada beberapa ketentuan yang bersifat kontesktual dan sangat dipengaruhi oleh kondisi sosial masyarakat sekitarnya, ${ }^{12}$ sehingga pada suatu waktu harus dilakukan reinterpretasi terhadap nilai-nilai AlQur'an sehingga ditemukan kembali semangat dasar perintah Tuhan dalam al Qur'an.

Salah satu permasalahan yang menjadi semangat perubahan nilai dari problematika dahulu untuk dirubah yang terkandung didalam Al-Qur'an adalah peroblematika perbudakan. Al-Qur'an jelas sekali menyatakan bahwa Tuhan sangat memuliakan anak-cucu adam. Q.S al-Isra' (17): 70, ungkapan anak cucu adam yang terdapat dalam kutipan di surat tersebut adalah semua manusia, tanpa perbedaan sedikitpun termasuk majikan dan budak. Namun kondisi sosial pada saat itu tidak memungkinkan untuk menghilangkan perbudakan, sehingga $\mathrm{Al}$ Qur'an dengan penafsiran maknanya yang secara tekstual memperbolehkan perbudakan, kendati demikian, seiring dengan gejolak pembebasan yang ada,

\footnotetext{
${ }^{12}$ Bandingkan dengan pernyataan Wansbrought tentang kontekstualisasi al-Qur'an dalam pengaruh kondisi sosial, "bahwa semua korpus dokumentasi Islam masa awal harus dipandang sebagai "sejarah penyelamatan". Apa yang dicoba dibuktikan oleh al Quran, dan apa yang dicoba dijelaskan oleh karyakarya tafsir, sirah dan teologi, adalah bagaimana rangkaian pristiwa dunia yang terpusat pada masa Muhammad diarahkan oleh Tuhan. Seluruh komponen "sejarah penyelamatan" Islam adalah sarana untuk menyelamatkan titik iman yang sama, yaitu pemahaman sejarah yang melihat peran Tuhan dalam mengarahkan urusan-urusan manusia. Andrew Rippin, "Analisis Sastra Terhadap Al Quran, Tafsir, dan Sirah", dalam Richard C. Martin, Pendekatan Kajian Islam dalam Studi Agama, judul asli "Approach to Islam in Religious Studies", terj. Zakiyuddin Bhaidawy, (Surakarta: Muhammadiyah University Press, 2002), hlm. 205.
} 
Khairul Mufti Rambe, Hak-Hak Perempuan Dalam Hukum Islam (Studi Pemikiran Ashgar Ali Engineer)

keberadaan perbudakan tersebut seakanakan sirna sedikit demi sedikit. Demikian juga dengan kesetaraan peran laki-laki dan peremepuan, QS Al-Baqarah (2): 228. Pada saat itu kondisi sosial juga tidak memungkinkan untuk memposisikan perempuan setara dengan laki-laki, sehingga lain Allah menambahkan ولرجال عليهن درجة. Dengan demikian, tidak semua teori Hukum Ila<hiyah bagi Engineer dapat diterapkan pada saat sekarang. Perbudakan dan posisi subordinat perempuan tentunya tidak dapat diterima lagi pada masyarakat modern. Dan hasilnya timbul dua pilihan, apakah kitab suci akan diabaikan atau harus dibaca ulang sesuai dengan kondisi masyarakat sekarang.

Atas dasar tersebut, menurut Engineer moralitas normatif dalam hal ini moralitas agama, walau bersifat transendent dia hanya dapat dipraktekkan dalam konteks tertentu. Ketika konteksnya berubah, bisa jadi tidak mungkin mempraktikkan moralitas dalam bentuknya yang lama, namun kandungan normatifnya tidak dapat dikorbankan ketika mengembangkan moralitas baru.

Bagi Engineer, menerjemahkan AlQur'an tentunya sesuai dengan pengalaman masing-masing penafsir dan penafsiran Al-Qur'an bukanlah monopoli ulama abad pertengahan. Pemahaman bahwa penafsiran Al-Qur'an hanya monopoli ulama abad pertengahan, hanya akan menimbulkan kebekuan pemikiran hukum Islam. Banyak yang menganggap hukum Islam tidak dapat lagi diubah, karena datang dari Tuhan. Mereka tidak menyadari bahwa dalam menetepkan hukum Islam terdapat banyak campur tangan ulama masa lalu, yang pada pada hakikatnya penetapan hukum terdahulu jika dilihat dari realitas sekarang sungguh jauh berbeda.

Tafsir merupakan hasil usaha ijtihadi manusia yang melingkupi dari segala dimensi pemikirannya untuk memproduksi suatu pemahaman dari kitab suci. Dalam penafisran manusia senantiasa akan membawa latar belakang sosial, corak dan warna keilmuan yang melandasi karya pendapatnya. Proses dialektik yang terjadi berintegrasi dengan kitab suci. ${ }^{13}$ Penafsiran bisa berubah dari satu zaman ke zaman yang lainnya, ia tidak berlaku abadi. Karena penafsiran selalu bersifat relatif dan terbatas. Sebuah penafsiran boleh berubah, namun AlQur'an tetap abadi. Kitab suci tidak lekang oleh waktu dan Muhammad sebagai figur dengan hidayah-Nya mampu menerjemahkan semangat dasar kitabullah dalam praktik hidup seharihari. ${ }^{14}$

Karena itu menurut Engineer, hukum Islam bukanlah hukum yang tertutup. Namun demikian dinamika vitalitasnya sangat tergantung terhadap selain itu, dan Engineer juga mendasarkan gugatan pada penghormatannya terhadap kesetaraan relasi laki-laki dan perempuan, hal inilah yang akan membentuk sebuah pola keadilan dalam dinamika keluarga.

Terkait dalam konteks Keluarga Islam, yang dalam hal ini menyangkut persoalan hak menerima dan mendapatkan mahar, Engineer memiliki pandangan yang berbeda tentang mahar,

\footnotetext{
${ }^{13}$ Naqiyah Najilah, Otonomi Perempuan, (Jatim: Bayumedia Publising, 2005), hlm. 88-89.

${ }^{14}$ Farha Ciciek, Jangan Ada Lagi Kekerasan dalam Rumah Tangga, cet-I (Jakarta:Gramedia Pustaka Utama, 2005), hlm. 23-24.
} 
baginya mahar bukanlah harga perempuan. Mahar menurutnya adalah ungkapan rasa cinta, ketulusan, dan kesungguhan. Mahar juga bukanlah untuk menunjukkan kelas sosial seseorang. Walau demikian dia tetap menganggap mahar sebagai bagian dari esensial perkawinan, karena mahar adalah hak perempuan yang harus dibayar oleh suami.

Dikarenakan bentuk esensial dari pernikahan, Engineer memahami, wanita bebas menentukan jumlah maharnya yang dia sukai dan mahar itu menjadi miliknya, bukan milik ayah atau suaminya, pemahaman tersebut merujuk kepada Q.S An-Nisa' (4): 4. Dari teks ayat tersebut Engineer juga memahami tidak ada batasan dalam menentukan jumlah besarnya mahar. Dan Al-Qur'an juga mengajarkan agar laki-laki memberikan mahar sebanyak mungkin sesuai dengan kemampunnya.

Hal lain yang menjadi pemahaman baru adalah tentang mendapatkan nafkah, Menurut Engineer, tidak hanya laki-laki yang dianjurkan untuk mencari nafkah, perempuan juga diperbolehkan untuk mencari nafkah. Bahkan dia juga memiliki kesempatan untuk mendapatkan kedudukan yang setara dengan laki-laki jika dia telah menjadi penyangga nafkah keluarga. Pemikiran seperti ini tentunya muncul kerena pengaruh masyarkat modern yang memandang biasa perempuan untuk bekerja di sektor publik. Bagi Engineer masyarakat pada masa Nabi adalah masyarakat yang memilki latar belakang sosial yang berbeda dengan masyarakat sekarang. Sehingga ketentuanketentuan yang berlaku pada masa itu adalah ketentuan yang hadir sesuai dengan kondisi sosial masyarakat sekarang.

Namun dalam persoalan ini menurut padangan penyusun Engineer tidak melakukan pemahaman yang jauh melanggar dari koridor yang telah ditentukan di dalam Al-Qur'an. Walau perempuan boleh mencari nafkah dan dapat memilih kedudukan yang setara dengan laki-laki jika telah mampu menjadi penyangga keluarga, bukan berarti tanggung jawab tersebut terlimpah secara keseluruhan terhadap perempuan, akan tetapi jikalau kemampuan itu dimiliki perempuan secara utuh kebolehan mencari nafkah terbuka lebar bagi diri perempuan. Bagi Engineer, tanggung jawab penuh berkenaan dengan nafkah tetap tercurahkan secara murni ditangan laki-laki.

Dalam ungkapan lain perihal nafkah, Engineer menambahkan, jika suami secara terus-menerus mengabaikan istri dan tidak mencukupi kebutuhan materialnya, istri berhak mengajukan perkara ini ke Pengadilan. Pengadilan berhak untuk memasukkannya ke penjara tanpa memeriksa si suami terlebih dahulu. Dan menurut sejumlah ahli fikih, hukumnya itu berkisar antara satu sampai tiga bulan. Perlu dicatat, meskipun istri setuju suaminya tidak perlu membayar biaya hidupnya, namun persetujuan ini tidak sah, karena mencukupi biaya hidup merupakan syarat objektif nikah dan persetujuan yang mempengaruhi hak istrinya itu tidak dapat dianggap benar. ${ }^{15}$

\footnotetext{
${ }^{15}$ Ashgar Ali Engineer, Islamn dan Teologi Pembebasan, terj. Agung Prihantoro, (Yogyakarta: Pustaka Pelajar, 2009), hlm. 244.
} 
Khairul Mufti Rambe, Hak-Hak Perempuan Dalam Hukum Islam (Studi Pemikiran Ashgar Ali Engineer)

Selanjutnya pemahaman baru yang dihasilkan dari pemikiran Engineer adalah menyangkut tentang persoalan hak mengajukan perceraian, bahwa nikah dalam Islam bersifat kontraktual. Dengan kata lain, baik pengantin laki-laki maupun pengantin perempuan dapat menetapkan syarat-syarat berlangsungnya pernikahan. Hal ini mengisyaratkan bahwa perempuan bebas untuk memutuskan apakah ia mau melakukan kontrak pernikahan atau tidak. Karena bersifat kontrak, perempuan bebas untuk mengajukan perceraian kapan pun ia mau. Hal ini mengisyaratkan bentuk kebebasan yang ada pada loyalitas perempuan, sebab perceraian merupakan bentuk alamiah dari sebuah pernikahan, akan tatapi perlu untuk diingat bahwa perceraian memang mengharuskan hubungan pisah diantara dua manusia dan karena itu sedapat mungkin harus dihindari, sebab Islam membolehkan perceraian tapi pada saat yang sama Islam mengajarkan perceraian sebagai abghad al-mubahat. Namun, dalam keadaankeadaan tertentu, perceraian menjadi mutlak diperlukan.

Hal yang lebih ditekankan dalam perceraian ini adalah, Engineer mengatakan bahwa tidaklah benar untuk mempertahankan suatu pendapat bahwa semua formasi Hukum Islam seluruhnya didasarkan pada perintah Kitab Suci, dan oleh karenanya tidak dapat diubah misalnya. Sebab, banyak formulasi Hukum Islam didasarkan pada hadis yang kontroversial dan pendapat para juris muslim. Jika ini diterima, akan lebih memudahkan untuk menerima perubahan tertentu yang diperlukan untuk memenuhi tantangan dunia modern yang berkaitan dengan Hukum Keluarga. Hal demikian sangat membantu kaum perempuan yang saat ini menemukan banyak hukum keluarga sangatlah tidak adil. ${ }^{16}$

Salah satu perobelmnya adalah "talak tiga" yang diucapkan sekaligus dalam satu waktu. Didalam mazhab Hukum Sunni Hanafi, talak tiga yang diucapkan sekali waktu diterima sebagai bentuk "talak yang sah", dan pengucapannya mengakibatkan perceraian yang tidak dapat dirujuk kembali. Bahkan, kalaupun laki-laki tersebut menyesal setelah itu, dia tidak dapat mengambil kembali istrinya kecuali jika istrinya tersebut kawin dengan orang lain, dan kemudian orang tersebut menceraikannya. Pada saat itulah perempuan tersebut dapat kawin dengan mantan suaminya. ${ }^{17}$

Hal seperti ini menimbulkan masalah besar bagi kebanyakan perempuan yang diceraikan. Bahkan, para ulama ortodoks merujuk bentuk perceraian ini dengan thalak bid'ah, atau bentuk talak yang di inovasi dengan mengandung dosa. Model perceraian seperti itu didasarkan pada hadis kontroversial yang mengatakan bahwa Nabi membolehkan "talak tiga" yang diucapkan sekali. Hadis yang lain yang sangat bertolak belakang dengannya, dan meskipun hadis tersebut kontroversial, tetapi talak tiga tetap disahkan. Oleh karena itu, banyak para ahli Hukum Islam terkemuka menolak validitas bentuk hadis ini. Imam Ibnu Taimiyah misalnya, menganggap ini thalak al-bid'i sebagai hal yang haram sangat dilarang. Para ahli

${ }^{16}$ Ashgar
Perempuan, hlm. 8
${ }^{17}$ Ibid.


hadis dan juris Islam Syafi'iah juga menolak validitasnya. Bagaimana mungkin, kemudian hukum tersebut dianggap sebagai perintah suci yang tidak bisa diubah? ${ }^{18}$

Pernikahan tidak dapat selalu dianggap sebagai ikatan yang dapat diputuskan. Apabila pernikahan diperlakukan sebagai sebuah sakramen, sebagaimana dalam agama Hindu dan Kristen, maka tidak dapat diputuskan dan karena itu perceraian tidak dimungkinkan.

Dan yang terakhir dari hak-hak perempuan dalam hukum keluarga Islam adalah menyangkut tentang hak aktualisasi diri, kitab suci Al-Qur'an telah memberikan keterangan yang sangat jelas bahwa perempuan mempunyai status individulanya sendiri sebagai bentuk dari pengembangan aktualisasi dirinya untuk dapat bekerja di luar rumah, sebagai landasan QS. At-Taubah (9): 105, hal ini menjadi acuan pemikiran Engineer, bahwa perempuan harus bisa memainkan peranan yang semakin besar. Mereka harus bisa bekerja untuk menjamin kehidupan keluarga yang sejahtera. Sebagaimana yang telah ditunjukkan, tidak ada ajaran dalam Al-Qur'an yang menghalangi perempuan bekerja. Sebaliknya, ia mengatakan bahwa apapun yang telah dia peroleh (makasabat) adalah miliknya sendiri. Pandangan bahwa seorang perempuan harus menjaga rumah dan mengasuh anak-anak adalah pandangan yang secara ketat tidak Qur'ani. Yang dituntut al-Qur'an bukanlah agar dia tidak dapat bekerja tetapi bahwa laki-laki harus menafkahi istrinya sebagai balasan kepada istri yang telah

\footnotetext{
${ }^{18}$ Ibid.
}

memilihara anak. Ini tidak melepaskan seorang perempuan dari haknya untuk bekerja ini hanya membangun kesejajaran antara istri dan suami.

Bagi Engineer, kesejajaran bukanlah sesuatu yang bersifat mandat. Istri dapat memilih bekerja atau membuat kesejajaran yang berada menurut mana keduanya akan menanggung biaya hidup keluarga, perawatan rumah, dan pemeliharaan anak. Apakah ini merupakan pengelolaan yang terbaik atau bukan ada masalah lain. Orang lebih suka kepada pengelolaan yang lain dengan kesepakatan bersama. Tetapi sejauh yang dinyatakan al Qur'an, tidak ada halangan bagi seorang perempuan untuk keluar rumah guna mencari nafkah, asalkan dia menjaga kesuciannya dan menahan diri dari dorongan seksualnya (wayahfadzna furujahunna), dan hal yang sama juga menuntut laki-laki untuk (wayahfadzna furujahum). Karena itu, laki-laki tidak lebih unggul dari perempuan dalam hal apapun.

Rasa ketidakadilan sering terjadi dan khususnya dirasakan oleh kaum perempuan dalam lingkup kehidupannya baik dalam lingkungan keluarga ${ }^{19}$ maupun dalam lingkungan publik. Laki-laki banyak

\footnotetext{
${ }^{19}$ Aktifitas perempuan yang bersifat reproduksi seperti menyusui dan memelihara anak memang tidak lepas dari tanggung jawab terhadap keluarganya, akan tetapi secara mutlak aktifitas tersebut seakan-akan memasuk hak dan peran perempuan sesuai keinginanya sebagai manusia. sebaliknya perempuan yang telah berkeluarga jangan terlalu merasa bebas sebebasbebasnya dalam melakoni aktifitasnya diranah publik, karena mengurus anak membina rumah tangga adalah merupakan amanah yang harus dilaksanakan secara bersama dengan tidak menitikberatkan pada salah satu pihak. Lihat Wahiduddin Khan, Agar Perempuan Tetap Menjadi Perempuan, cet ke-II (Jakarta: Serambi, 2003), hlm. 226.
} 


\section{Engineer)}

yang kurang sempurna, bahkan lemah moralnya, tetapi mengapa selalu perempuan yang menjadi korbannya, menjadi orang yang tersalahkan bahwa bisa sebagai objek penderita. ${ }^{20}$ Padahal, di ranah publik Islam mengakses yang adil bagi perempuan. ${ }^{21}$ Aktifitas mencari ilmu, mencari nafkah, melakukan transaksi (positif), dan bahkan aktifitas politik juga dibuka untuk perempuan. Sama seperti laki-laki, semua itu harus dilakukan secara terhormat dan bermartabat.

Pencegahan perempuan untuk tidak keluar rumah dalam arti bekerja di luar rumah sebagaimana yang telah dimaksudkan di dalam Al-Qur'an (wayahfadzna furujahunna) adalah

${ }^{20} \mathrm{Ibid}$, hlm. 126-127. Menguatnya gugatan tentang ketidadilan terhadap perempuan dalam berbagai lapangan kehidupan, merupakan hasil dari gerakan kebangkitan perempuan (tahrir al mar'ah) diseluruh dunia. Dengan berbagai argumennya, gerakan ini menyatakan bahwa perempuan telah ditindas oleh sebauah tradisi yang mengutamakan lakilaki, dan menganggap perempuan hanya sekedar makhluk kelas dua yang ditaqdirkan untuk mengukuhkan tradisi tersebut. Salah satu pangkal ketidakadilan terhadap perempuan bermuara dari stereotip yang cendrung merendahkan, yang ditujukan pada perempuan, Lihat Siti Musdah Mulia, Keadilan dan Kesetaraan Gender (Jakarta: TIM Pemberdayaan Perempuan Bidang Agama Departemen Agama RI, 2001), hlm. 82.

${ }^{21}$ Sangat ironis ketika sejumlah ulama bersalah saat mencabut hak kaum perempuan yang telah diberikan Allah kepada mereka: hak untuk hidup mandiri memenuhi kebutuhan sehari-hari mereka tidak hanya melalui amal-amal spiritual tetapi juga melalui kegiatan ekonomi yang produktif. Lihat, Kaukah Siddque, "The Strunggle of Muslim Women", terj. Arif Maftuhi, Menggugat Tuhan Yang Maskulin, cet-I (Jakarta: Paramadina, 2002), hlm. 95. Islam tidak menetapkan hukum yang mengatakan bahwa hanya wanita saja yang seharusnya memasak, mencuci, dan merawat anak,. Dalam ranah keluarga, jika suami memutuskan dengan sukarela bahwa istri akan menjaga rumah dan suami bekerja diluar rumah, Islam tidak keberatan dalam hal ini. Keduanya juga dapat bekerja diluar rumah dan bekerja secara Islami. Ibid. hlm. 96-97. sebagai bentuk penjagaan diri, agar lebih mewaspadai diri dan menjaga kehormatan. Kendati demikian, pada dasarnya permintaan kepada perempuan untuk tidak ke luar rumah sendirian dikarenkakan takut akan ganggguan maka permintaan ini tidak bisa menjadi status prinsip, sebagaimana yang telah dilakukan. Jika beberapa undang-undang dilaksanakan karena adanya situasi darurat maka undang-undang tersebut harus segera dicabut, setelah masa darurat itu berlalu. Atau, undang-undang tersebut dibuat dengan jelas bahwa ia secara esensial dimaksudkan untuk melindungi perempuan, dan tidak bisa diberlakukan terhadap situasi dimana ketakutan seperti itu tidak ada. Meskipun demikian, tradisi sosial sering kali menjadi masalah keyakinan keagamaan dan segera memproleh status prinsip. ${ }^{22}$

Dengan demikian, realisasi prinsip kebebasan harus diberlakukan kepada perempuan. Sebab kebebasan merupakan salah satu hak dasar hidup setiap orang dan merupakan pengakuan sebagai seorang yang merdeka dan meningkatkan kemuliaan harkat martabat kemanusiaan dihadapan jenis kelamin yang lain. Bila prinsip kebebasan ini dibelenggu maka yang akan terjadi adalah penindasan dari jenis kelamin tertentu, bahkan merusak dari tatanan nilai-nilai Qurani sebagai ummat yang satu ummatan wahidah.

\section{Relevansi dengan Perkembangan Pemikiran Islam Modern}

Sehubungan dengan konstruksi pemikiran Engineer dari beberapa

${ }^{22}$ Ashgar Ali Engineer, Pembebasan Perempuan, (Yogyakarta: LKiS, 1999), hlm. 266. 
pengaruh filsuf, relevansi dari gagasan Engineer akan diperlihatkan terhadap perkembangan pemikiran Islam modern terhadap posisi perempuan dalam Hukum Keluarga Islam. Hukum keluarga Islam yang dimaksud adalah hukum keluarga yang mengatur hubungan internal anggota keluarga muslim terutama yang berkenaan dengan masalah perkawinan (munakahat). ${ }^{23}$ Namun dalam gagasan yang ditawarkan Engineer terhadap hakhak perempuan dalam hukum keluarga Islam tidak akan diurai dari semua ruang lingkup hukum keluarga Islam. Namun dalam hal ini Engineer hanya memberikan ide-ide pembebasannya dari konsep teologi yang berkembang yang pada akhirnya membentuk pola hukum yang tidak mendeskriditkan posisi perempuan, baik dalam sisi hak maupun kesetaraan kehidupan.

Kesetaraan "kesejajaran" dan keseimbangan sebagai prinsip utama keadilan harus diagendakan dalam rangka pembentukan suatu fikih baru yang berperspektif keadilan gender. Keadilan gender yang dimaksud adalah memandang setara "sejajar" dan seimbang kedudukan laki-laki dan perempuan, tidak berdasarkan pada perbedaan-perbedaan yang bersifat kodrati. Ketika berbicara tentang keadilan, maka yang dimaksud adalah keadilan yang terjadi di alam relitas, bukan keadilan di alam abstrak. ${ }^{24}$

Berangkat dari realitas bahwa keadilan merupakan perinsip utama yang harus dipatuhi dalam konteks upaya

${ }^{23}$ Muhammad Amin Suma, Hukum Keluarga Islam di Dunia Islam, (Jakarta: Raja Grafindo, 2005), hlm. 21.

${ }^{24}$ Agus Nuryatno, Islam dan Teologi Pembebasan dan Kesetaraan Gender, hlm. vii. penegakan keadilan adalah al-musa>wah yang berarti memperlakukan semua pihak secara sejajar di depan hukum atau peradilan. Dan prinsip yang tidak kalah pentingnya adalah at-taswiyah, yaitu upaya menyamakan antara hak satu dengan hak yang lain. Itu hanya bisa ditempuh dengan mengambil sesuatu dari tangan orang yang tidak berhak, dan mengembalikannya kepada orang yang berhak.

Dengan demikian, berbicara tentang "persamaan" sejatinya adalah berbicara tentang hak asasi manusia sebagai makhluk yang merdeka. Sebagai makhluk yang merdeka, manusia selalu mendambakan terpenuhinya hak-hak mereka secara wajar atas nama keadilan. Adalah sebuah kebohongan besar bila seruan penegakan keadilan tidak disertakan dengan upaya mewujudkan prinsip persamaan hak tersebut. Persamaan hak inilah yang seharusnya menjadi concern setiap penegak hukum, utamanya mereka yang memiliki kekuasaannya. Keinginan sementara pihak untuk mendapat prioritas khusus mengalahkan yang lain hanya akan mencederai rasa keadilan bersama. Karena itu tidak ada seorang pun yang boleh diperlakukan secara diskriminatif atas nama apa pun, termasuk agama. ${ }^{25}$

Dalam membentuk sebuah pengembangan pemikiran baru dalam Hukum Islam, Muhammad Al Khaduri seorang ahli Hukum Islam terkemuka di Mesir berpendapat, bahwa Al-Qur'an telah meletakkan tiga prinsip dasar dalam

${ }^{25}$ Dalam, "Tafsir Tematik", Hukum, Keadilan, dan Hak Asasi Manusia, (Jakarta: Lajnah Pentashihan Mushaf al Quran, 2010), hlm. 176. 
Khairul Mufti Rambe, Hak-Hak Perempuan Dalam Hukum Islam (Studi Pemikiran Ashgar Ali Engineer)

pengembangan pembentukan Hukum enam belas abad sejarahnya. ${ }^{29}$ Teks Islam bernilai keadilan dengan menjadi penentu bagi eksistensi menjunjung tinggi sosialisasi ajaran Islam peradaban Islam. Bahkan saking yang disebut dengan tarikh at-tasyri', yang dominannya, 'Ali Harb sampai-sampai mempunyai tiga perinsip utama: Pertama, menyatakan bahwa yang membentuk berangsur-angsur dalam menetapkan peradaban Islam adalah teks, dan hukum (tadrij at-tasyri). Kedua, menghilangkan kesulitan-kesulitan ('adam al-haraj). Ketiga, menyedikitkan peraturan (taqlil at-taqlif). ${ }^{26}$

Dari beberapa bentuk pengembangan fikih baru dalam Hukum Islam tersebut merupakan dasar Hukum Islam, yakni kemaslahatan manusia harus diingat ketika menyusun hukum apa pun yang harus diikuti manusia. ${ }^{27}$ Atas dasar tersebut menurut penulis konteks sosial adalah sebagai bagian dari bahan pertimbangan ketika menentukan aturanaturan yang berkaitan dengan hukum personal atau yang dikenal dengan ahwal al-syakhshiyah. Bagi Descartes kebenaran dan manusia merupakan pelaku utama sejarah, dan baginya relitas itu (ada) sangat ditentukan dan diciptakan oleh kesadaran. ${ }^{28}$

Sebagaimana dimaklumi, teks tidak saja menempati posisi sentral dalam perkembangan dan pengambangan peradaban Islam termasuk didalamnya ilmu-ilmu keislaman, namun sekaligus menjadi inspirator dan pemandu bagi gerakan-gerakan umat Islam sepanjang

26 Muhammad al Khaduri Bek, Tari $>k h$ atTa>syri' al-Isla>mi>, (Beirut: Dar al-Fikr, 1967), hlm. 15

${ }^{27}$ Ashgar Ali Engineer, Pembebasan Perempuan, (Yogyakarta: LKiS Aksara Yogyakarta, 1999), hlm. 252.

${ }^{28}$ Imam Iqbal, Makalah, disampaikan pada Diskusi Ilmiah Dosen Tetap UIN Sunan Kalijaga, Tanggal 17 Mei 2013, "Refleksi Atas Cara Kita Berteologi", (Yogyakarta: Sekretariat Diskusi Ilmiah Dosen Tetap UIN Sunan Kalijaga, 2013), hlm. 4.

Dari tatanan pengembangan hukum Islam tersebut menjadi tantangan besar untuk bisa merevisi dari beberapa pasal UU Perkawinan yang masih merugikan perempuan, penerapan pengaturan yang relatif yang memadai di dalam UU Perkawinan masih menjadi pertanyaan. Dalam implementasinya, akses perempuan terhadap hak-haknya yang relatif dijamin di dalam UU Perkawinan masih jauh dalam; akibat kuatnya budaya dan praktek-praktek yang lebih bersandar pada pemahaman terhadap adat, kebiasaan dan penafsiran keagamaan ketimbang kebijakan Negara. Praktekpraktek demikian masih meletakkan perempuan menjadi subordinat di wilayah domestik dan marginal di publik.

Reformasi hukum keluarga yang menjadi agenda besar bagi upaya untuk memposisikan perempuan sebagai makhluk yang setara. Reformasi tidak saja merupakan kebijakan Negara namun juga pada institusi-institusi hukum, sosial dan di dalam pola pikir masyarakat yang senantiasa masih tetap mengadopsi nilainilai patriarki.

Tawaran teologi pembebasan Engineer memberikan titik terang pada problematika kemanusiaan dan perubahan zaman. Dalam sejarah

\footnotetext{
${ }^{29}$ Hasan Hanafi, al Yamin wa al Yasar fi al Fikr ad Dini, (Mesir: Madbuli, 1989), hlm. 77

${ }^{30}$ Ali Harb, Hermeneutika Kebenaran, terj. Sunarwoto Dema (Yogyakarta: LKiS, 2003), hlm. 31
} 
perkembangan pemikiran Islam sejak lebih dari dua dekade yang lalu, gagasan menghidupkan kembali teologi rasional telah muncul dikalangan ummat Islam Indonesia, gagasan ini muncul sebagai antithesis dari fenomena teologi tradisional yang dipandang telah menyebabkan keterbelakangan umat.

Pada perkembangan berikutnya terjadi kontroversi teologi tradisional dan teologi rasional dalam mendapatkan koreksi karena dianggap berhenti pada tataran ide dan konep, tetapi tidak dapat menyelesaikan persoalan konkrit yang dihadapi manusia. Berbagai ketidakadilan dan penindasan dalam kehidupan bermasyarakat memerlukan keberadaan rumusan teologi yang menekankan perhatian dari pemikiran pada gerakan sosio-kulutural yang bermuara pada transformasi sosial umat dalam kehidupan berbangsa dan bernegara.

Kehadiran Engineer memberikan jawaban terhadap persoalan kemanusiaan tersebut. Sebagai seorang pemikir yang memperjuangkan gagasan kebebasan, perdamaian, keadilan dan berbagai term kemanusiaan lainnya, asimilasi nilai (value), ide Engineer telah teruji karena kehadirannya, bukan hanya sebagai pemikir, tetapi juga seorang aktifis, pejuang, dan pembela kaum tertindas dalam melawan kezaliman. Hal ini menggambarkan semangat juang dalam menyelesaikan problematika masyarakat dengan melakukan metode perubahan sosial dengan cara aplikatif.

Salah satu problem kemanusiaan yang hingga sekarang belum terselesaikan adalah persoalan perempuan adalah konsep kepemimpinan, baik pemimpin dalam ranah domestik maupun dalam ranah publik, sehingga terdapat berbagai faktor penyebab ketidakadilan terhadap perempuan dan utamanya adalah rumusan teologi yang melegimitimasi ketidakadilan tersebut.

Dengan menguraikan alasan,
penulis berpendapat bahwa
kontektualisasi kepemimpinan rumah tangga memberi peluang akan terpilihnya pemimpin yang benar-benar memenuhi persyaratan dan dalam pandangan Engineer, lebih sesuai dengan prinsip kesetaraan antara laki-laki dan perempuan. Namun penulis, melihat terdapat kelemahan pokok yang menjadi kontekstualisasi kepemimpinan dalam wilayah domestik ini. Walau kelihatannya lebih adil, tapi akan mengalami kesulitan dalam menentukan siapa yang lebih unggul secara fungsional, dan bagaimana kalau kedua-duanya secara objektif memiliki keunggulan yang sama. Apabila hal tersebut terjadi tentu alternatifnya adalah kepemimpinan kolektif. Kelihatannya kepemimpinan kolektif tersebut lebih demokratis karena masingmasing punya hak yang sama. Tapi kesulitan tersebut akan muncul tatkala antara keduanya tidak tercapai kata sepakat dan jalan musyawarah mengalami kebuntuan.

Di Indonesia, pada tahun 1984 Pemerintah telah meratifikasi konvensi penghapusan segala bentuk kekerasan terhadap perempuan. Namun demikian implementasi dari konvensi tersebut dihadapkan pada kendala politis dan sosiologis. ${ }^{31}$ Kendala politis terkait dengan

${ }^{31}$ Ciciek Farkha, "Perspektif Perempuan dalam Penegakan Hak Asasi Manusia", dalam Tabloid Sehat, no. 31 Juli 2000, P3M, Jakarta, 2000, hlm. 
Khairul Mufti Rambe, Hak-Hak Perempuan Dalam Hukum Islam (Studi Pemikiran Ashgar Ali Engineer)

sikap ambivalen pemerintah dalam menempatkan Hak Asasi Manusia sebagai parameter untuk menetapkan kebijakan pembangunan secara keseluruhan. Disisi lain, kebijakan umum Negara tentang keperempuanan masih banyak bertentangan dengan konvensi. Sebagai contoh adalah pasal 30 UU No. 1/1974 ayat 3 yang menyebutkan bahwa suami adalah kepala keluarga dan istri adalah ibu rumah tangga. Pembakuan peran secara normatif tersebut mempunyai implikasi yang luas bagi perempuan, utamanya berkaitan dengan berbagai produk kebijakan baik di sektor publik ataupun sektor domestik. Jika laki-laki dan perempuan secara kodrati diakui sebagai mitra sejajar yang saling melengkapi, saling membutuhkan dan saling berketergantungan, sehingga harkat serta martabat dapat dicapai baik oleh laki-laki atau perempuan dengan perjuangan, maka pernyataan tersebut tidak seharusnya muncul dan dicantumkan dalam ketetapan hukum. Kodrat, harkat dan martabat perempuan sayangnya lebih merupakan konstruksi masyarakat yang dikaitkan dengan status perempuan sebagai ibu rumah tangga atau istri dan bukan perempuan sebagai manusia perempuan.

Hegemoni permikiran teologi klasik yang diskriminatif dan tekstualis tidak mampu menyelesaikan dari the rise of education utamanya pada dunia perempuan yang menempatkan teologi pada posisi marginal karena secara normatif dipandang tidak relevan dengan realitas kehidupan, yang pada akhirnya penempatan teologi tersebut berdampak pada tatanan hukum keluarga Islam di Indonesia yang justru mengadakan pembatasan terhadap perempuan. Asumsi dasar yang mengatakan bahwa hukum dapat mewujudkan keadilan dan kesejahteraan dalam kenyataannya tidak terbukti. Hukum justru sering dijadikan sarana untuk merampas sumber daya ekonomi, politik, sosial dan budaya masyakarat, sehingga hukum lebih berfungsi melanggengkan proses kemiskinan.

Telah banyak pemikir yang memberikan solusi dengan memberikan berbagai pendekatan yang berbeda pula, dan persoalan teologis bermuara pada persoalan metodologi interpretasi. Metodologi yang dipakai pada umumnya metodologi pada ulama klasik adalah dengan membedakan dalil-dalil qat'i dan zanni, yang medefenisikan qat'i sebagai dalil yang secara semantik clear dan tidak dapat diubah, sementara yang zanni bersifat ambigu.

Persoalannya adalah jika digunakan metodologi interpretasi semantik seperti itu, seluruh isi perempuan masuk dalam kategori qat'i dan tidak dapat diubah atau diberikan interpretasi lain selain apa yang secara tekstual tersurat. Amina wadud, menawarkan rekonstruksi metodologi dengan menggunakan pendekatan Hermeneutik. Namun demikian metode ini tidak mudah dan mengandaikan pengetahuan yang komprehensif sekitar dunia teks, dunia author, dan dunia audience termasuk berbagai hal yang berkaitan dengan ilmu-ilmu kemanusiaan yang lain.

Kendati demikian, tidak mudah mengubah satu sistem yang telah mengakar dan menjadi idiologi selama berabad-abad. Persoalan perempuan tidak hanya melibatkan perempuan tetapi juga laki-laki yang dalam hal ini berada 
dibawah posisi tidak mudah. Gagasan Engineer mengandaikan bahwa jika rumusan teologi sebelumnya ialah menempatkan laki-laki pada posisi lebih tinggi dan suprioritas diatas perempuan, maka munculnya teologi rasional dan bahkan liberal transforamtif mengandaikan kebesaran jiwa laki-laki untuk dapat berdiri sama tinggi dan duduk sama rendah dengan perempuan.

Sebaliknya, perempuan harus siap dengan rumusan status ontologisme yang menempatkan eksistensinya sebagai individu yang otonom dengan segala konsekwensinya. Sebagai manusia lakilaki, Engineer membuktikan objektifitas pemikirannya yang berimplikasi pada pemberian ruang dan tempat yang egaliter bagi perempuan sekaligus meretas asumsi suprioritas yang dimiliki laki-laki. Prejudice yang berkaitan dengan kepentingan individu tidak relevan disifatkan pada upaya pembebasan dan penegasan otonomi dan hak-hak perempuan yang dilakukan Engineer.

Menurut Engineer, Islam memiiki nilai-nilai inti (the central values) di antaranya keadilan, tindakan yang wajar terhadap semua orang (fairplay), persaudaraan, persamaan, kasih sayang, dan belas kasih. Nilai-nilai tersebut secara umum menentang kekerasan dan menghendaki terwujudnya kedamaian, dan dalam Al-Qur'an gambaran nilai-nilai tersebut menggunakan term ma'ruf yang merupakan representasi komperhensif dari kebaikan di dalam kemanusiaan.

Dalam wacana studi agama kontemporer, langkah-langkah metodologis Engineer merupakan tawaran ideal yang dapat memberikan alternatif jawaban terhadap persoalan dikhotomis antara norma agama di satu sisi dan historisitas disisi lain. Pertentangan pendekatan normatif dan historis memunculkan klaim bahwa pendekatan kedua kurang menyentuh aspek batiniyah, esoteric dan makna terdalam dari moralitas agama.

Jika normatif minded menyebabkan orang traliensi dari lingkungannya, maka sebaliknya terjerat pola pikir budaya lokal juga menyebabkan spilit personality. Agama dalam era globalisasi mendapat tantangan berat. Asumsi dasar dari agama adalah bahwa manusia memerlukan pegangan hidup yang tetap, sementara kehidupan selalu berubah. ${ }^{32}$ Penganut agama dituntut untuk berfikir universal substansial sehingga tidak kehilangan nilai-nilai fundamental normatif dari ajaran kegamaan. Namun demikian, pada saat yang sama mereka juga dituntut untuk bertindak susuai dengan ruang dan watku, terikat batas-batas weltranshaung yang terbentuk oleh faktor sejarah, geografis, dan berbagai hal yang bersifat historis partikular.

Berbagai gagasan segar dan transformatif memberikan nilai positif pada pemikiran Engineer, namun demikian serba terbatas dan hanya Tuhan merupakan kebenaran tak terbatas. Tidak ada hal yang sempurna lahir dari sesuatu yang terbatas.

Fokus perhatian pada persoalan rekonstruksi yang menempatkan hak individu sebagai agent of change, dan tugas individu manusia untuk mempelajari Islam dan merefleksikan secara

${ }^{32}$ Amin Abdullah, Filsafat Kalam di Era Post Modernisme, cet-I, (Yogyakarta: Pustka Pelajar, 1995), hlm. 48 . 
Khairul Mufti Rambe, Hak-Hak Perempuan Dalam Hukum Islam (Studi Pemikiran Ashgar Ali Engineer)

mendalam, telah membuat Enginner melalaikan realitas konkrit dalam kehidupan bahwa tidak setiap individu memiliki kemampuan reflektif dan menciptakan perubahan. Hal terpenting dalam beragama menurut Engineer adalah bagaimana memikirkan ulang dan menginterpretasikan kembali berbagai isu di dalam Islam selaras dengan perkembangan dan perubahan zaman. Namun demikian tawaran metodologi yang mengandaikan kemampuan analisis dan kesadaran akan religiusitas yang tinggi ini tidak mungkin dapat dilakukan oleh setiap orang. Tingkat pendidikan dan intelektual individu atau komunitas akan memberikan pengaruh besar pada reflektif tersebut.

Gagasan Engineer dengan demikian hanya akan dapat dilakukan dan direalisasikan oleh kalangan tertentu dan tidak berlaku bagi masyarakat dengan tingkat pendidikan rendah. Pengandaian tentang masyarakat tanpa kelas dan penekanan pada peran setiap individu dalam merumuskan Islam bagi dirinya tidak akan terwujud selama kapasitas intelektual dan pendidikan masyarakat tidak merata.

Kesulitan lain yang berkaitan dengan indikator dan parameter sesuatu dapat dikatakan sebagai norma ideal, karena bagi Engineer jika kondisi konkret lebih kondusif bagi norma tersebut, maka norma ideal akan diterapkan atau setidaknya usaha maksimal untuk mendekati norma tersebut dan ukuran kebenaran adalah masyarakat. Jika norma ideal telah diterapkan dalam kehidupan suatu masyarakat maka norma tersebut telah berada pada wilayah sejarah dan dengan demikian menjadi kontekstual dan partikular. Bagaimana menentukan indikator ideal dalam wilayah kontekstual, sedangkan ukuran kebenaran adalah masyarakat yang bersifat historis dan partikular.

Persoalan lain yang dihadapi dunia pemikir Islam ialah problematika kemanusiaan. Gambaran penindasan pihak yang kuat terhadap yang lemah, tirani kekuasaan dipihak tertentu, dominasi sistem kapitalistik dan keterasingan manusia dari eksistensinya, menjadi agenda penting dalam upaya memanusiakan manusia dan menjamin kesejahteraan manusia. Agenda penting dunia pemikiran dengan demikian adalah agenda pembebasan manusia. Engineer hadir memberi pencerahan dalam agama Islam sebagai jalan pembebasan. Agama sebagai religius yang senantiasa menyatakan keterlibatan emosi yang tulus dengan visi moral dan spiritual untuk memperjuangkan hakikat kemanusiaan manusia. Semangat agama yang humanis, liberal dan progresif akan memberikan jalan menuju pada pembebasan manusia dari segala bentuk penindasan, kekerasan, ketidaksewenangan dan ketidakadilan yang menyebabkan kesengsaraan manusia.

Dengan memberikan konsep metodologi yang ditawarkan Engineer sosiologi-history perjuangan perempuan akan memainkan peranan penting dalam segala ruang. Dan ketika konsep tersebut ditinjau dari segi ruang publik, maka ketika laki-laki melindungi perempuan, ini berarti yang dilindungi laki-laki adalah sosiologi bukan teologis. Memang demikian, kelebihan laki-laki sebagai 
pemberi nafkah adalah juga fungsi sosial. ${ }^{33}$ Sebab Engineer beralasan menempatkan Islam sebagai agama yang mempunyai titik perhatian pada keadilan sosial untuk membebaskan kaum yang lemah dan tertindas serta menciptakan masyarakat yang egalitarian adalah merupakan salah satu bentuk ketaqwaan.

Dengan demikian, dari beberapa penawaran Engineer terhadap pemahaman baru yang ditawarkan, dan faktor penyebab pemikirannya, serta relevensi pemikannya terhadap perkembangan pemikiran Islam Modern, penulis akan memetakan bahwa, Islam tidak bermaksud mempertahankan kehidupan manusia yang bersifat eksploitatif, akan tetapi Islam pada dasarnya mempunyai nilai (value) untuk merubah ummat ke arah yang lebih baik, dengan membentuk kesetaraan dalam berkehidupan dan menciptakan keadilan sosial. Disebabkan manusia hidup dalam bentuk sosial bermasyarakat maka perlu diciptakan hukum yang benar-benar relevan tidak memihak kepada siapapun dan sangat mementingkan keselamatan individu diatas kepentingan umum. Atas dasar kesetaraan dan keadilan dalam pembentukan hukum tersebut diharapkan hukum bisa menyelaraskan diberbagai realitas kehidupan manusia, baik yang menyangkut tentang hukum publik maupun hukum yang bersifat personality atau dikenal dengan ahwal al-syakhshiyah.

\section{SIMPULAN}

\footnotetext{
${ }^{33}$ Khoruddin Nasution, Fazlurrahman Tentang Wanita, cet ke-1 (Yogyakarta: LKiS, 2003), hlm. 103104.
}

Bahwa perkembangan yang ada dalam pemikiran Ashgar Ali Engineer adalah perkembangan mengenai konsep teologi Pembebasan. Ini adalah merupakan poin terpenting dalam pemikirannya, dengan menjadikan teologi sebagai ideologis utama dalam membebaskan yang kaum yang tertindas dengan metode rekonstruksi pemikiran yang bersifat traditional-teologic-modern, serta melakukan pembedaan antara pernyataan normatifitas Al-Qur'an dengan pernyataan kontekstualitas Al-Qur'an dalam merefleksikan kembali ajaranajaran agama yang lebih relevan, hal ini berguna untuk mengetahui perbedaan antara apa yang sebenarnya diinginkan oleh Allah dan apa yang dibentuk oleh realitas masyarakat pada waktu itu. Kedua pendangan tersebut adalah merupakan cerminan dari kekayaan Al-Qur'an, sebab kitab suci tidak hanya berbicara tentang masyarakat ideal, atau apa "yang seharusnya," akan tetapi juga mempertimbangkan realitas empiris, atau apa "yang terjadi". Dengan demikian, tidak ada konsep superior-inferior dalam agama khususnya dalam bidang keluarga, yang ada hanyalah hubungan mitra sejajar dalam arti saling membutuhkan dan saling mengisi antara satu dengan yang lain.

Selanjutnya, atas dasar inkulturasi pemikiran, seseorang tidak akan muncul tanpa latar belakang historisitas-kulutural dan pengalaman yang dimiliki, dan perkembangan yang ada dalam pemikiran Ashgar Ali Enginner adalah merupakan bentuk dari generalisasinya di bidang ilmu filsafat. Dari genialisasi tersebut digunakannya untuk merefleksikan kembali tentang kebenaran realitas kehidupan dengan mempelajari filsafat 
Khairul Mufti Rambe, Hak-Hak Perempuan Dalam Hukum Islam (Studi Pemikiran Ashgar Ali

\section{Engineer)}

Barat yang pada umumnya filsafat Karl Marx. Selain dari itu ada beberap filsuf yang menjadi faktor penyebab pemikirannya, antara lain : Bertrand Russel, Hegel, Spinoza, Karl Marx, dan seorang sastrawan Sir Muhammad Iqbal. Memuat faktor penyebab pemikiran Engineer dari konstruksi pemikiran Marx dengan melahirkan sebuah konsep sejarah manusia tidak bisa diatur oleh hukumhukum yang tidak bisa diubah hanya dengan campur tangan individu-individu yang didorong oleh cita-cita atau kepentingan tertentu.

Dari faktor penyebab pemikiran tersebut, maka akan didapat relevansi yang dihasilkan dari konstruksi pemikiran Ashgar Ali Engineer, adalah membentuk pola pemikiran modern yang menyelaraskan rumusan hukum yang senantiasa segar dan transformatif berdasarkan nilai-nilai ketuhanan, dengan melahirkan pola hukum yang setara dan adil khususnya dalam Hukum Keluarga Islam. Sebab Hukum Islam atau yang disebut dengan fikih, menurut Engineer merupakan hukum yang bersifat situasional dan bukan transendental dan karenanya harus diterapkan secara kreatif dalam berbagai kondisi yang berbeda dan berubah. Dinamika ini di bangun dengan menggunakan metodologi yang menekankan pendekatan sosio-teologis yang progresif, yang berorientasi pada humanisme ala Islam. Sehingga diharapkan tercipta kondisi yang penuh dengan kebebasan dan kesetaraan dengan menghasilkan pola keadilan yang distribusi dan menolak keras segala penindasan dan eksploitasi dengan pola memanusiakan manusia. Bagi Engineer, Hukum Islam haruslah mengacu pada nilai-nilai fundamental yang terkandung di dalam Al-Qur'an, yaitu: 'adl (keadilan), ihsan (kebajikan), rahmah (kasih sayang), hikmah (kearifan) dan menjunjung tinggi martabat manusia, maka dengan demikian, akan tercipta keadilan gender dengan membangun relasi antara laki-laki dan perempuan dalam konteks kesetaraan dan keadilan yang sesuai dengan nilai-nilai semangat Al-Qur'an. Pola pemikiran tersebut senada dengan Muhammad alKhaduri seorang ahli Hukum Islam terkemuka di Mesir berpendapat, bahwa dalam membentuk sebuah pengembangan pemikiran baru dalam Hukum Islam, AlQur'an telah meletakkan tiga prinsip dasar dalam pengembangan pembentukan Hukum Islam yang bernilai keadilan dengan menjunjung tinggi sosialisasi ajaran agama Islam yang disebut dengan tarikh at-tasyri, dengan mempunyai tiga perinsip utama yang harus dibangun: Pertama, berangsur-angsur dalam menetapkan hukum (tadrij at-tasyri). Kedua, menghilangkan kesulitan-kesulitan ('adam al-haraj). Ketiga, menyedikitkan peraturan (taqlil at-taqlif).

\section{DAFTAR PUSTAKA}

Al-Sadawi, Nawawi, Perempuan dalam Budaya Patrialki, terj. Zulhilmiyasri (Yogayakarta: Pustaka Pelajar, 2001)

Ananda , Faisar, Wanita Dalam Konsep Islam Modernis, (Jakarta: Pustaka Firdaus, 2004)

Ali Engineer , Ashgar, Islam dan Teologi Pembebasan, terj. Agung Prihantoro, (Yogyakarta: Pustaka Pelajar, 2009)

Ali Engineer, Ashgar, Pembebasan Perempuan, (Yogyakarta: LKiS, 1999)

Amin Suma Muhammad, Hukum Keluarga Islam di Dunia Islam, (Jakarta: Raja Grafindo, 2005Shahrur, Muhammad, Metodologi Fikih Islam Kontemporer, terj. Syahiron Syamsuddin, (Yogyakarta: Elsak, 2004)

al Khaduri Bek Muhammad, Tari $>$ kh at-Ta $>$ syri' alIsla>mi>, (Beirut: Dar al-Fikr, 1967) 
Abdullah, Amin, Filsafat Kalam di Era Post Modernisme, cet-I, (Yogyakarta: Pustka Pelajar, 1995)

C. Martin, Pendekatan Kajian Islam dalam Studi Agama, judul asli "Approach to Islam in Religious Studies", terj. Zakiyuddin Bhaidawy, (Surakarta: Muhammadiyah University Press, 2002)

Ciciek, Farha, Jangan Ada Lagi Kekerasan dalam Rumah Tangga, cet-I (Jakarta:Gramedia Pustaka Utama, 2005).

Ciciek, Farkha "Perspektif Perempuan dalam Penegakan Hak Asasi Manusia", dalam Tabloid Sehat, no. 31 Juli 2000, P3M, Jakarta, 2000

Hanafi Hasan, al Yamin wa al Yasar fi al Fikr ad Dini, (Mesir: Madbuli, 1989)

Harb Ali, Hermeneutika Kebenaran, terj. Sunarwoto Dema (Yogyakarta: LKiS, 2003)

Iqbal Imam, Makalah, disampaikan pada Diskusi Ilmiah Dosen Tetap UIN Sunan Kalijaga,

Ilyas Hamim, Perempuan Tertindas: Kajian Haditshadits Misoginis, (Yogyakarta: eLSAQ Press, 2003), hlm. 51.

Ishaq Ibrahim ibnu Ali ibnu Yusuf al-Fairuzzabady, Abi, al-Muhazzab fi Mazhab al-Imam asySyafi i (Beirut: Dar al Fiqr, 1994 M/1414 H).

Nuryatno Agus, Islam dan Teologi Pembebasan dan Kesetaraan Gender.

Nasution Khoruddin, Fazlurrahman Tentang Wanita, cet ke-1 (Yogyakarta: LKiS, 2003)

Najilah, Naqiyah, Otonomi Perempuan, (Jatim: Bayumedia Publising, 2005).

Quraisy Shihab M., Membumikan Al-Qur'an fungsi dan Peran Wahyu dalam Kehidupan Masyarkat, cet XXII (Bandung: Mizan, 2001), hlm. 26. Lihat juga Muhammad al Ghazali, alIslam wa at-Thaqat al-Mu'attalat, (Kairo: Dar al-Kutub al-Haditsah, 1964).

Rippin, Andrew, " Analisis Sastra Terhadap Al Quran, Tafsir, dan Sirah", dalam Richard

Siddque, Kaukah, "The Strunggle of Muslim Women", terj. Arif Maftuhi, Menggugat Tuhan Yang Maskulin, cet-I (Jakarta: Paramadina, 2002.

Umar ,Nasaruddin, Qur'an untuk Perempuan, (Jakarta: Jaringan Islam Liberal, dan Teater Utan Kayu, 2002).

Wahiduddin, Khan, , Agar Perempuan Tetap Menjadi Perempuan, cet ke-II (Jakarta: Serambi, 2003).

Wahono Fr. Nitiprawiro, Teologi Pembebasan: Sejarah, Metode, Praksis dan Isinya, cet I, (Yogyakarta: LKiS, 2002). 